\title{
Static and dynamic effects of Mercosur. The case of the footwear sector
}

\section{Marta Bekerman}

Director

bekerman@econ.uba.ar

\section{Pablo Sirlin}

Researcher

sirlin@econ.uba.ar

Centre for Economic

Structural Studies (CENES)

Faculty of Economics,

University of Buenos Aires
The static effects of trade creation or diversion are generally held to be the essential variable for evaluating the costs and benefits of regional integration. However, it is the effects of a dynamic nature that provide the most convincing arguments in favour of integrating economies rather than opening them up unilaterally. The difficulties involved in measuring these effects make it necessary to isolate aspects that can provide a basis for analysing the changes undergone by the different production sectors and the consequences of these for the levels and types of industrial organization, business strategies, technological modernization and the regional dynamic, among other things. The footwear sector is very useful when it comes to analysing the effects of subregional integration, as it is a sector that displays rising trade flows within and outside the area, with small and medium-sized enterprises (SMEs) playing an important role. It forms part of a larger production chain, and its competitiveness depends on systemic factors.

This article consists of five sections. Section I describes the main characteristics of the footwear sector. Section II analyses the regulatory and microeconomic policy framework within which the sector operates nationally and subregionally. Section III describes the structure and performance of the sector in the 1990s. Section IV analyses the static and dynamic effects that can be identified from statistical analysis and the fieldwork carried out in Argentina, Brazil and Uruguay. ${ }^{1}$ Lastly, by way of conclusion, section $\mathrm{V}$ deals with the inherited and acquired advantages of the footwear industry.

\footnotetext{
${ }^{1}$ These studies involved conducting the same standardized interview with around fifteen firms from each of the countries concerned and with the main business organizations in the sector.
} 
I

\section{Basic characteristics of the footwear sector}

The footwear industry is part of a production chain that begins with cattle rearing and leather production and then moves on to the industrial phase, which comprises three stages: the cold-storage plant and slaughterhouse stage, then the tannery stage and, lastly, the manufacture of leather goods, including footwear. If the footwear produced is not made wholly from leather, the manufacturers concerned are also linked with the rubber and plastics production chain. In addition, footwear manufacturing links back to a range of supporting industrial activities, among them the production and importation of footwear parts and components, cardboard boxes and machinery and equipment for the industry.

The output of the sector is not homogeneous. Not only is the product range highly varied (sports, formal or special shoes, shoes for men, women or children, shoes made entirely of leather, plastic or rubber or a combination of these, etc.), but within a single category of footwear products are differentiated by quality, brand, etc. This variety has led to considerable segmentation of the footwear market, which determines the characteristics of competition in the sector.

Price competition is very important, particularly where lower-quality footwear is concerned. With higher-quality footwear, product differentiation is the key factor. In the sports footwear category, brand image plays a fundamental role and advertising and marketing costs are consequently a central feature.

In the formal footwear segment economies of scale are not decisive (something that has not been changed by the technological innovations that are being introduced into the industry) and in many countries footwear production is carried out mainly by SMEs. Economies of scale seem to be more important in the sports footwear segment, so plants tend to be larger. Again, the importance of brands means that the world market for sports footwear is dominated by a small

$\square$ This paper is part of a wider project coordinated by the authors, the national studies on Argentina, Brazil and Uruguay having been carried out by CENES, FUNCEX (Centre for Foreign Trade Studies Foundation) and CINVE (Centre for Economic Research) number of major international brands that supply the world market through their own production plants in different locations (often in countries with cheap labour) or through production and/or marketing licences. The same is true, to a lesser extent, in the higher-quality segments of the formal footwear category.

Since price is a crucial feature of competition in the sector, cost reduction is a key element in companies' competition strategies. Labour is a particularly important cost since, despite the introduction of new automated technologies, the production process is still labour-intensive. Consequently, the availability of lowwage labour has been a key factor in competitiveness for this industry and in the shift of production from developed countries to economies with low-cost labour (first Taiwan, the Republic of Korea, Hong Kong and Brazil then, in a second stage, China, the Philippines and Indonesia).

Similarly, the availability of raw materials (natural leather) of the requisite quality and price has been another determining factor for competitiveness in the industry, although it now seems to be declining in importance as characteristics such as quality, design, delivery times and production efficiency come to the fore, and as the variety and quality of leather substitutes increase (Da Costa, 1993).

From the technological point of view, the industry is highly diverse, and in many countries there are still a great many small firms using traditional technology. Nonetheless, there are certain innovations -computeraided design (CAD) and production- that have become increasingly important to competitiveness and are being adopted more and more widely in the sector. In some market segments, such as women's footwear, that have a particularly wide and frequently changing model range, the introduction of CAD has enabled plants to achieve the flexibility of production needed to meet demand.

respectively operating as part of the INTAL (Institute for the Integration of Latin America and the Caribbean) RedInt network of centres. The authors are grateful for the comments of one of the anonymous assessors working at the CEPAL Review. 


\section{II}

\section{The microeconomic policy framework}

\section{National trade and sectoral regulation policies}

During the import substitution industrialization phase, the Mercosur countries, and particularly Argentina and Brazil, developed a vast range of promotional instruments that combined high rates of trade protection with special investment incentive regimes and, subsequently, with instruments to stimulate exports. In the late 1980s came the first signs of a strategy change in economic policy which was to take hold at differing speeds and with differing degrees of thoroughness in the various countries.

In the 1990s, moves towards greater economic openness in Argentina and Brazil began to result in a substantial reduction in the nominal and actual protection provided to the footwear sector. Despite these general tendencies towards rationalization and declining public-sector intervention in industrial policy, however, both countries still retain different policy instruments that have benefited the sector.

In 1994 Argentina established specific minimum duties for a range of sports footwear categories, and these were increased in 1995. In 1997 a safeguard clause providing for the application of specific minimum duties (from which the Mercosur countries are exempted) came into effect, and in November 1998 this was extended to provide for import quotas (if these are exceeded, specific duty levels double). Lastly, in 1999 Argentina tried to implement para-tariff measures designed to hinder imports, mainly from Brazil.

In the case of Brazil, incentives provided by the federal Government overlap with those of state governments, which have greater powers to provide tax incentives than do their Argentine counterparts. The federal Government has taken a range of measures to support the sector. Between 1995 and 1998, the National Development Bank (BNDES) set up an investment financing programme for the sector with a preferential interest rate. Meanwhile, the Brazilian Government began to make more active use of external trade policy. In 1995 it placed a large number of tariff categories relating to the footwear sector on the list of exceptions to the common external tariff, and a tariff of $31 \%$ was set for these, to be gradually reduced from 2000 onwards. In April 1997 the federal Government used
Provisional Measure 1569 to place certain restrictions on import financing, although these were eventually eased somewhat for Mercosur members (exceptions were granted for imports of less than US\$ 40,000 with a term of up to 89 days). ${ }^{2}$

\section{Sectoral regulation and trade policies in the context of Mercosur}

At the subregional level the relevant policy areas are connected with the movement towards subregional free trade in the sector, implementation of the common external tariff, the reduction or elimination of restrictions or taxes on exports of hides within Mercosur and the harmonization of incentive policies among member countries.

Trade liberalization within Mercosur is a relatively recent process. Right from the outset, many of the most significant tariff positions of Argentina and Uruguay were on their respective lists of exceptions to intrazonal trade liberalization and, once the Customs Union had been set up in 1995, most of these positions came to form part of their adjustment regimes. Thus, it was only in 1995 that a gradual process of intrazonal tariff reduction began in the cases of Argentina and Uruguay, a process that ended in 1999 and 2000, respectively. Brazil also created obstacles to intrazonal free trade, essentially by means of Provisional Measure 1569 of 1997 restricting import financing, which has already been touched upon.

The common external tariff for the footwear sector was originally $20 \%$, a level similar to that of nominal tariffs in Argentina and Uruguay and slightly higher than the Brazilian tariff. However, the pressure of imports from outside Mercosur (mainly from SouthEast Asia) at a time of currency appreciation led the Governments of Argentina and Brazil to place a number of the sector's products on their lists of exceptions to the common external tariff (with a timetable for reducing duties that was to bring them into line with the common external tariff in 2001). In addition, Argentina has

\footnotetext{
2 This measure would have had serious effects on Argentine exports, as was confirmed by interviews with the Chamber and with one of the companies exporting footwear to Brazil.
} 
lodged a national safeguard clause against imports of footwear originating outside the area, something that has deepened subregional differences as regards external trade policy and benefited trading partners within the area. Thus, where the footwear sector is concerned Mercosur has not yet become a true customs unions.

One issue that has given rise to conflict and intense negotiations is the imposition by Argentina and Uruguay of restrictions and taxes on leather exports. The Uruguayan restrictions were eventually lifted, while in Argentina a timetable has been laid down for reducing intrazonal export duties to zero by 2000 .

Lastly, there is still the crucial problem of regulatory discrepancies between the member countries of Mercosur. Harmonization of industrial policies within the area was laid down as one of the priorities in the 1991 Treaty of Asuncion, but very little progress has been made so far. Against this background, the noticeably more active approach being taken by the federal and state governments of Brazil (mainly through the fiscal battle to attract investment) would appear to be creating a highly asymmetrical context for intraregional competition. This situation has been instrumental in complicating relations between the employers' organizations of the member countries, which are characterized more by conflict than by cooperation. Meanwhile, the lack of harmonization in numerous areas of industrial policy is being compounded by non-compliance with community decisions already signed up to.

\section{III}

\section{Structure and performance of the sector}

\section{Structure of the footwear sector in Mercosur}

The Mercosur footwear sector is composed of a very heterogeneous collection of different-sized companies, a few large enterprises coexisting with numerous small and medium-sized ones (tables 1 and 2).

In the three countries considered the structure of this sector takes the form of a pyramid, with a large base of microbusinesses and small enterprises, a substantial number of medium-sized firms and a relatively small number of large ones (tables 1 to 5).

Leaving aside this similarity, there are large differences between the different Mercosur countries as regards the number of companies operating in the sector (8,500 in Brazil, 1,400 in Argentina, 117 in Uruguay) and in their size: the number of companies with more than 100 employees is 435 in Brazil, 30 in Argentina and just 2 in Uruguay.

In Argentina there is a clear distinction between the sports footwear and the non-sports footwear segments. The sports footwear segment is highly concentrated: at one extreme there are two big producers of branded sports footwear (Alpargatas Calzados S.A. and Gatic S.A.), whose various plants around the country account for $95 \%$ of all footwear of this type produced nationally (CLAVES, 1997). These companies are licensed by the main international brands (Nike in the case of Alpargatas Calzados S.A. and Adidas, New

$\begin{aligned} & \text { TABLE } 1 \\
& \text { Argentina: Concentration in the footwear } \\
& \text { sector, 1993 } \\
& \text { (Argentine pesos) }\end{aligned}$
\begin{tabular}{lcc} 
& \\
\hline Size of firm by & Number of & $\begin{array}{c}\text { Percentage of sectoral } \\
\text { output by gross value }\end{array}$ \\
gross output value & firms & 23 \\
\hline Under 1 million & 1.222 & 27 \\
1 to 5 million & 136 & 20 \\
5 to 20 million & 23 & 30 \\
Over 20 million & 7 &
\end{tabular}

Source: Prepared by the authors using data from the National Institute of Statistics and Censuses (1994).

\begin{tabular}{|c|c|c|c|}
\hline $\begin{array}{l}\text { Size of firm by } \\
\text { number of } \\
\text { employees }\end{array}$ & $\begin{array}{l}\text { Number } \\
\text { of firms }\end{array}$ & $\begin{array}{c}\text { Total } \\
\text { employees }\end{array}$ & $\begin{array}{c}\text { Total turnover } \\
\text { (millions of reals) }\end{array}$ \\
\hline Under 10 & 6334 & 16174 & 266 \\
\hline 10 to 49 & 1387 & 30874 & 438 \\
\hline 50 to 99 & 344 & 24200 & 349 \\
\hline 100 to 249 & 259 & 40535 & 644 \\
\hline Over 250 & 176 & 177170 & 3220 \\
\hline Total & 8500 & 288953 & 4917 \\
\hline
\end{tabular}

Source: Correa (1999). 
TABLE 3

Uruguay: Concentration in the footwear sector, 1997

\begin{tabular}{lcc}
\hline $\begin{array}{l}\text { Size of firm by } \\
\text { number of employees }\end{array}$ & $\begin{array}{c}\text { Number } \\
\text { of firms }\end{array}$ & $\begin{array}{c}\text { Percentage of total } \\
\text { number of firms }\end{array}$ \\
\hline Under 10 & 77 & 65.8 \\
10 to 19 & 27 & 23.1 \\
20 to 100 & 11 & 9.4 \\
Over 100 & 2 & 1.7 \\
\hline
\end{tabular}

Source: Laens, Osimani and Failde (1999).

Balance and Le Coq Sportif in the case of Gatic S.A.). In addition, Alpargatas Calzados S.A. has consolidated a brand of its own (Topper) which it sells not just in Argentina but elsewhere in Latin America as well. A third company (Unisol S.A.) produces sports footwear under the Puma and Lotto brands, although on a considerably smaller scale. At the other extreme, there are a number of small firms producing lower-priced sports footwear without international branding, which they sell in regional markets.

The non-sports footwear segment, which is subdivided by the type of user (men, women, children) and by product quality and price, is highly fragmented. There is just one leading firm (Grimoldi S.A.) which works with its own brands and foreign licences, but whose output is no more than $10 \%$ of that of the big sports shoe manufacturers. Besides this, there are a few medium-sized companies and a multitude of small ones whose gross output is less than five million pesos.

In Brazil, three big groups of companies can be identified in the footwear sector. The large producers (over 450 employees) specialize essentially in sports footwear and the bulk of their sales are in the domestic market; they produce under international licences and have a few brands of their own that are established in specific niches. At the other extreme, small firms and microbusinesses also operate in local markets, but use more artisanal production methods.

Lastly, medium-sized enterprises (between 50 and 449 employees) mainly concentrate on foreign markets and tend to be located in the state of Rio Grande do Sul, specifically in the Valle de Sinos region, which has played a vital role in the vigorous export performance of the sector. ${ }^{3}$ Footwear production in this region was started off by a conglomeration of small firms focused on the domestic market. Over recent decades, this has turned into a group of different-sized companies that now export 70\% of their output (Schmitz, 1997).

${ }^{3}$ Between 1970 and 1990 Brazil increased its share of world leather footwear exports from $0.5 \%$ to $12.3 \%$.
In Uruguay, there are just two big footwear producers (over 100 employees), which export most of their output (one concentrates on the United States market and the other on the Argentine one). Medium-sized and small enterprises basically produce for the domestic market and occasionally export.

\section{Performance of the sector}

\section{a) Production and apparent consumption}

In 1997, footwear production in the three Mercosur countries being studied was US\$ 4.2 billion at current prices, of which Brazil accounted for $71 \%$, Argentina for $24 \%$ and Uruguay for $5 \%$. The sector has developed erratically, but there has been a clear mediumterm tendency for production, and to a lesser extent apparent consumption, to stagnate or fall (figures 1 to 3 ).

From figures 1 to 3 the following general tendencies can be deduced for the period from 1991 to 1997 :

- The trend in footwear production was erratic, with a tendency for output to stagnate (Argentina) or fall (Uruguay and Brazil).

- Apparent consumption was sluggish, even though gross output in the area increased substantially during the period.

In the three countries studied there was a large increase in imports which eventually reversed the positive trade balance that had traditionally been a feature of the sector in Uruguay and Argentina. Imports also rose substantially in the case of Brazil, but the trade balance remained in surplus thanks to large export volumes.

\section{b) Employment and productivity in the footwear in- dustry}

According to the statistics available, the footwear industry of the three countries studied employed around 310,000 people in 1995 . Of this total, 288,000 were accounted for by Brazil, 20,000 by Argentina and just over 2,000 by Uruguay. ${ }^{4}$

Between 1988 and 1998 the number of employees in the sector fell greatly in all the countries analysed (by over 50\% in Uruguay and 20\% in Argentina). This was the result of stagnant or falling output and rising productivity (figures 4 to 6 ).

These charts show that productivity improved considerably in the footwear industries of Brazil and Argentina and evinced great volatility in Uruguay.

\footnotetext{
${ }^{4}$ We believe that the employment figures for the sector may be distorted by the informal nature of some of its activities.
} 
FIGURE 1

Argentina: Output and apparent consumption of footwear, 1988 to 1997

(Millions of 1993 Argentine pesos)

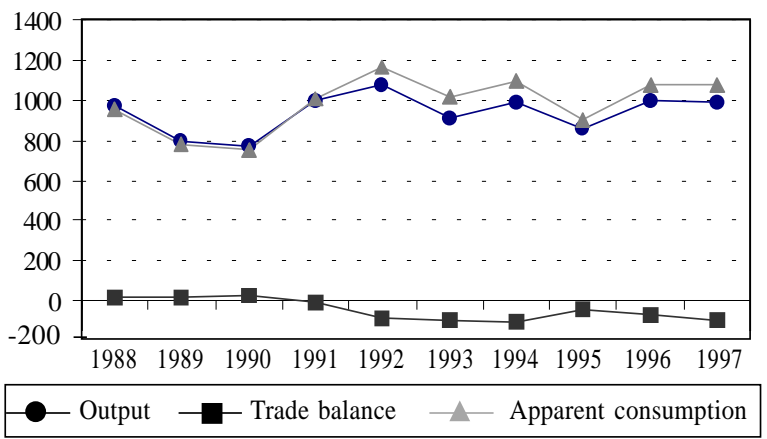

Source: Prepared by the authors using data from the National Institute of Statistics and Censuses (1997).

FIGURE 2

Uruguay: Output and apparent consumption of footwear, 1991 to 1997

(Millions of 1993 Uruguayan pesos)

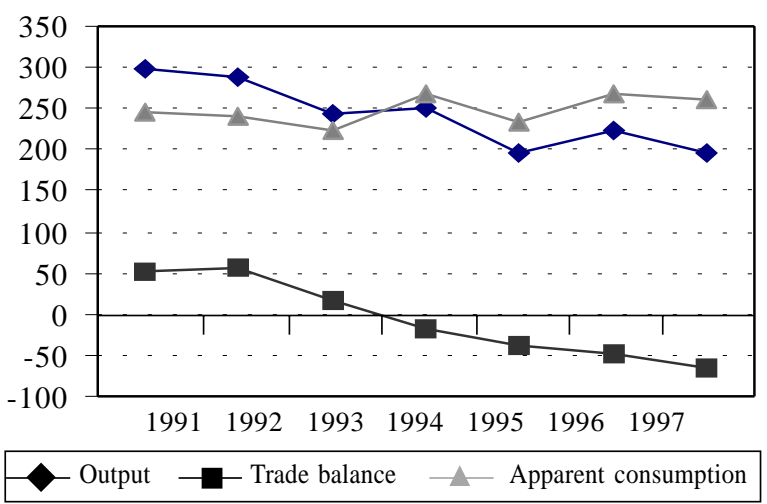

Source: Prepared by the authors using data from Laens, Osimani and Failde (1999).

FIGURE 3

Brazil: Output ${ }^{\mathrm{a}}$ and apparent consumption of footwear, 1989 to 1997

(Millions of 1993 Uruguayan pesos)

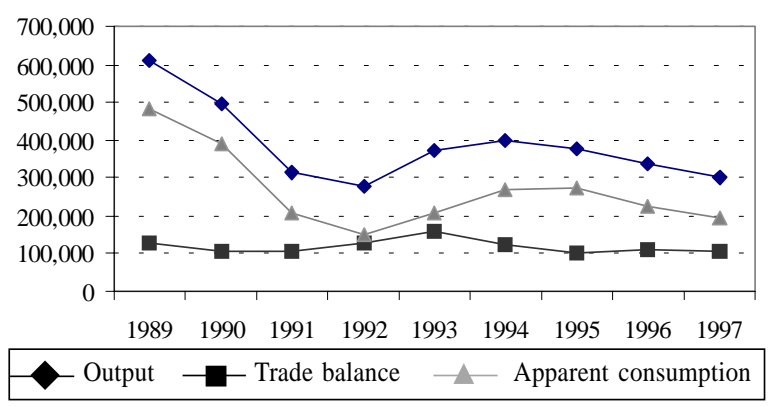

Source: Prepared by the authors using data from Correa (1999).

a The output series includes the clothing sector.
FIGURE 4

Brazil: Productivity, output volume and personnel employed in the footwear industry, ${ }^{a} 1988$ to 1998 (Index: $1990=100$ )

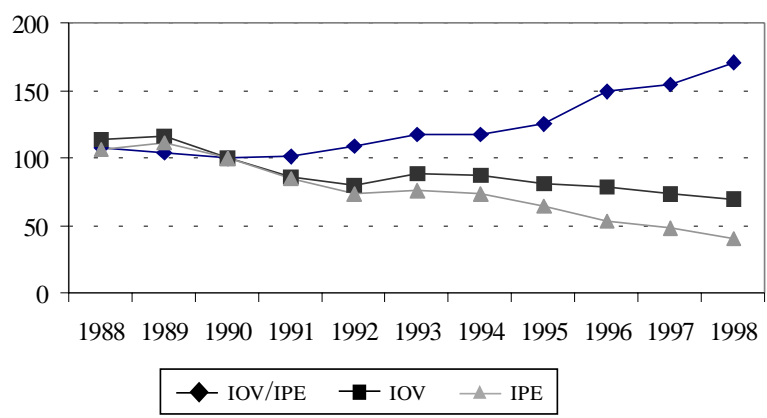

Source: Correa (1999).

a IOV: Index of output volume. IPE: Index of personnel employed.

FIGURE 5

Argentina: Employment and productivity in the footwear industry, 1985-1989 to 1997

(Category 324 in the International Standard Industrial Classification, Rev. 2. Index: $1990=100$ )

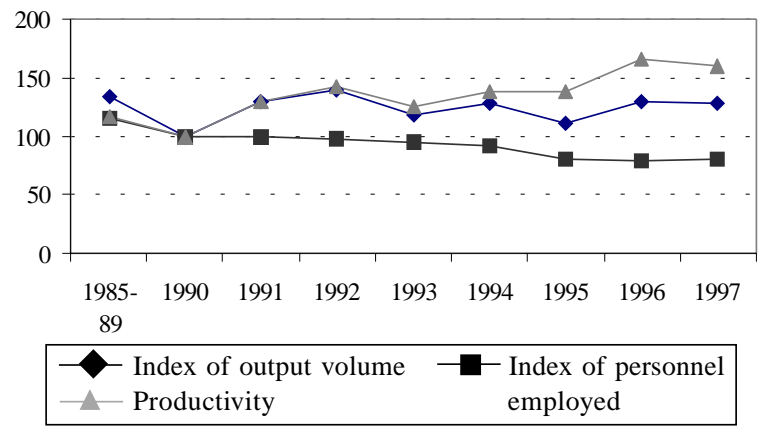

Source: Prepared by the authors using data from the National Institute of Statistics and Censuses (1997).

FIGURE 6

Uruguay: Employment and productivity in the footwear industry, 1991 to 1997

(Index: $1991=100)$

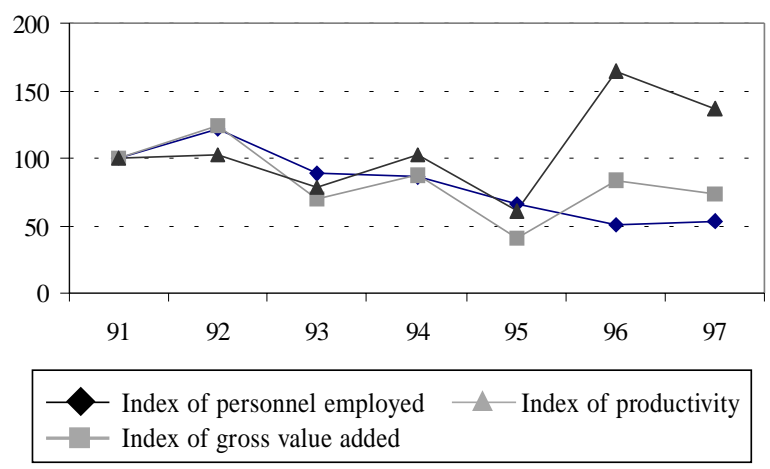

Source: Laens, Osimani and Failde (1999). 
TABLE 4

Mercosur: Factors of competitiveness in the footwear sector

\begin{tabular}{llll}
\hline Country & Argentina & Brazil & Paraguay \\
\hline Availability of raw materials & Very good & Good & Reasonable \\
Availability of labour & Reasonable & Abundant & Poor \\
Cost of labour & High & Low & Low \\
Skill level of workforce & Reasonable & Good & Low \\
Installed capacity & Reasonable & High & Low \\
Production technology & Reasonable & Very good & Poor \\
Company size & Medium & Large & Small \\
Business maturity & Reasonable & High & Low \\
Production scale & Medium & High & Low \\
Supplier network & Poor & Very good & Bad \\
Capital goods & Poor & Good & Low \\
Technical infrastructure & Reasonable & Very good & Medium \\
Government support & Nil & High & Poor \\
\hline
\end{tabular}

Source: UNIDO (1993).

\section{Competitiveness}

The competitive situation of the footwear industry varies greatly between the different countries of Mercosur. A study by the United Nations Industrial Development Organization (UNIDO, 1993) provides a highly revealing account of the factors involved in competitiveness (table 4).

From the study referred to, it can be concluded that the Argentine footwear industry is facing a clear problem of competitiveness. The changes that have taken place in the country in recent years (which are not covered by that study) can be seen to involve considerable progress in production technology and somewhat lesser progress in business maturity. However, the high degree of import penetration seen in the country during the 1990s suggests that the overall picture remains negative. Most of the companies consulted said that lack of cost competitiveness was a major barrier to exporting. ${ }^{5}$ The availability of an ample supply of good-quality leather does not translate into a competitive advantage for footwear companies, because the demand they generate is relatively small by comparison with export demand, so that the price and quality conditions they obtain locally are the same as or worse than those obtained by foreign buyers.

The Brazilian footwear industry, by contrast, has managed to consolidate its competitiveness in international markets. As the UNIDO study shows, Brazil has succeeded in coupling the advantages conferred by

${ }^{5}$ Lack of competitiveness as regards quality, by contrast, is a fairly minor problem. an abundant supply of cheap labour with different factors conducive to systemic competitiveness: a good supply of locally produced raw materials and capital goods, a substantial technical infrastructure and highly skilled labour. Some authors link the competitive success of certain Brazilian regions such as the Valle de Sinos with the existence of external economies of agglomeration and the collective endeavour of the companies themselves (Humphrey and Schmitz, 1996). The latter is based on cooperation by individual firms (lending of equipment and tools or new product development) or groups of firms joining forces to set up trade associations or production consortia. As a result of this collective action, six industrial associations have been formed in the Valle del Sinos, along with four centres providing technical services and training and a trade fair organization (FENAC) which has played an important role in forging relationships with foreign buyers, particularly in the United States (Schmitz, 1997).

In the face of increasing penetration of the United States market by low-priced Chinese leather footwear, Brazil has been obliged in recent years to raise the quality of its products and reduce delivery times. This has led to new forms of cooperation between Brazilian firms right along the production chain, which has gradually increased trust between them and helped them take the action necessary to consolidate their competitiveness (Schmitz and Knorringa, 1999).

Although on the whole the analysis of competitiveness shows Brazil in a better light, the competitive situation varies between the different segments of the sector. In sports footwear Argentina is relatively well placed, chiefly as regards products with more value 
added and greater technological content. The lower wage costs of Brazil are offset in Argentina by high quality and productivity.

Where non-sports footwear is concerned, the competitive situation of Argentina is much more fragile than that of Brazil, owing both to macroeconomic variables (wage levels and a high real exchange rate, the latter following the recent devaluation of the real) and to microeconomic ones (technological capabilities, economies of scale, workforce skill levels) and the position as regards public-sector incentives. Problems of competitiveness are found right along the Argentine production chain whereas, for the reasons referred to, the conditions for the supply of raw materials and inputs (except for leather) are better in Brazil, i.e., the production chain is better structured.

\section{Mercosur trade with the rest of the world}

\section{a) Global exports and imports}

The external footwear trade of Mercosur underwent marked changes in the 1990s. Between 1990 and 1996 the area's exports grew by $42 \%$ (table 5) while imports increased by $1,108 \%$, albeit from a very low base (table 6). The regional trade of the sector continued to show a substantial surplus (table 7).

The overall figures for the footwear sector in Mercosur, though, mask very different national situations. Brazil accounts for around $95 \%$ of footwear exports from the area and is the only country that still has a trade surplus in this sector.

In Argentina, substantial growth in footwear imports led to a large trade deficit from 1992 onwards. Trade restrictions and a significant increase in exports partially reversed the deficit in 1995 and 1996.

The footwear industries of Uruguay and Brazil export between $30 \%$ and $40 \%$ of their output by value. Argentina's, on the other hand, has a very low export coefficient, as its focus is almost exclusively on the domestic market.

\section{b) Origin and destination of Mercosur external trade in footwear}

The geographical origin and destination patterns of footwear exports from the different countries of Mercosur between 1988 and 1996 differed considerably (table 8 ). Over $90 \%$ of Brazil's exports went outside the area and only a marginal (although growing) share went to Mercosur countries. Argentina, on the other hand, sent more and more of its exports to these countries (almost $75 \%$ in 1996), while its exports to the rest of the world declined in absolute terms. Uruguayan exports followed a similar pattern, although to a lesser degree. From this it can be deduced that exports to Mercosur have ended up by replacing the exports that the two latter countries used to send to the rest of the world.

The imports of the Mercosur countries also displayed differing geographical patterns (table 9). In Brazil, the share of intrazonal imports increased greatly, but imports from outside the zone remained much higher. In Argentina, the proportion of imports originating in Mercosur, mainly Brazil, also grew rapidly (to reach 50\% in 1998). In Uruguay, however, the share of intrazonal imports fell over the 1990s.

\section{Trade within Mercosur}

\section{a) Intrazonal exports and imports}

As a result of the regional integration process, trade within Mercosur has been more dynamic than extrazonal trade. In fact, exports (imports) within the zone rose by $570 \%$ between 1990 and 1996 (tables 10 and 11).

The structure of intrazonal trade in the footwear sector, however, is very different from that of the sector's overall trade. Up until 1996 the leading export position of Brazil, which accounted for $60 \%$ of intrazonal exports in that year, was appreciably less marked in intrazonal trade than in trade with the rest of the world. Argentina, by contrast, was far more dynamic as an exporter within the zone.

As regards intrazonal imports, the most salient fact is that Brazil remained virtually closed to exports from the other Mercosur countries until 1994. Its imports (from Argentina) grew strongly from that year onwards, however, with the result that the structure of intrazonal imports came to resemble that of imports from outside the zone more closely. As a consequence of these developments, intrazonal trade balances were very different from those with the rest of the world: Brazil had a fairly modest surplus, while Argentina alternated between deficits and surpluses in different years. From 1997 onwards, the position of Argentina deteriorated sharply, with a growing deficit emerging in sectoral trade with Brazil. 
TABLE 5

Mercosur: Footwear exports, 1990 to 1996

\begin{tabular}{|c|c|c|c|c|c|c|c|}
\hline & 1990 & 1991 & 1992 & 1993 & 1994 & 1995 & 1996 \\
\hline \multicolumn{8}{|c|}{ A. Thousands of dollars } \\
\hline Argentina & 33084 & 35807 & 24472 & 30605 & 33655 & 75227 & 50566 \\
\hline Brazil & 1104766 & 1176660 & 1409156 & 1859818 & 1537351 & 1413780 & 1567403 \\
\hline Uruguay & 16844 & 18530 & 22952 & 24903 & 20735 & 17082 & 19949 \\
\hline Paraguay & 12 & 372 & 51 & 32 & 1199 & 115 & 147 \\
\hline Mercosur & 1154706 & 1231369 & 1456631 & 1915358 & 1592940 & 1506204 & 1638065 \\
\hline \multicolumn{8}{|c|}{ B. Percentages } \\
\hline Argentina & 3 & 3 & 2 & 2 & 2 & 5 & 3 \\
\hline Brazil & 96 & 96 & 97 & 97 & 97 & 94 & 96 \\
\hline Uruguay & 1,5 & 2 & 2 & 1 & 1 & 1 & 1 \\
\hline Paraguay & - & - & - & - & - & - & - \\
\hline Mercosur & 100 & 100 & 100 & 100 & 100 & 100 & 100 \\
\hline
\end{tabular}

Source: Prepared by the authors using data from INTAL (1997).

TABLE 6

Mercosur: Footwear imports, 1990 to 1996

\begin{tabular}{|c|c|c|c|c|c|c|c|}
\hline & 1990 & 1991 & 1992 & 1993 & 1994 & 1995 & 1996 \\
\hline \multicolumn{8}{|c|}{ A. Thousands of dollars } \\
\hline Argentina & 3515 & 44416 & 110868 & 128373 & 141463 & 114232 & 116587 \\
\hline Brazil & 18524 & 33107 & 12108 & 34785 & 84277 & 201829 & 199958 \\
\hline Uruguay & 2958 & 7960 & 12393 & 21146 & 22708 & 24854 & 32050 \\
\hline Paraguay & 6471 & 10288 & 7114 & 11239 & 21418 & 35238 & 32002 \\
\hline Mercosur & 31468 & 95771 & 142483 & 195543 & 269866 & 376153 & 380597 \\
\hline \multicolumn{8}{|c|}{ B. Percentages } \\
\hline Argentina & 11 & 46 & 78 & 66 & 52 & 30 & 31 \\
\hline Brazil & 59 & 35 & 8 & 18 & 31 & 54 & 53 \\
\hline Uruguay & 9 & 8 & 9 & 11 & 8 & 7 & 8 \\
\hline Paraguay & 21 & 11 & 5 & 6 & 8 & 9 & 8 \\
\hline Mercosur & 100 & 100 & 100 & 100 & 100 & 100 & 100 \\
\hline
\end{tabular}

Source: Prepared by the authors using data from INTAL (1997).

TABLE 7

Mercosur: Trade balance of the footwear sector, 1990 to 1996

(Thousands of dollars)

\begin{tabular}{lrrrrrrr}
\hline & 1990 & 1991 & 1992 & 1993 & 1994 & 1995 \\
\hline Argentina & 29569 & -8609 & -86396 & -97768 & -107808 & -39005 \\
Brazil & 1086242 & 1143553 & 1397048 & 1825033 & 1453074 & 1211951 & 1367445 \\
Uruguay & 13886 & 10570 & 10559 & 3757 & -1973 & -7772 & -12101 \\
Paraguay & -6459 & -9916 & -7063 & -11207 & -20219 & -35123 \\
Mercosur & 1123238 & 1135598 & 1314148 & 1719815 & 1323074 & 1130051 & 1257468 \\
\hline
\end{tabular}

Source: Prepared by the authors using data from INTAL (1997).

STATIC AND DYNAMIC EFFECTS OF MERCOSUR. THE CASE OF THE FOOTWEAR SECTOR • MARTA BEKERMAN AND PABLO SIRLIN 
TABLE 8

Mercosur: Intrazonal exports of member countries, 1988-1996

(Percentages)

\begin{tabular}{lrrrrrrr}
\hline Origin & 1988 & 1989 & 1990 & 1991 & 1992 & 1993 & 1994 \\
\hline Brazil & 1 & 1 & 1 & 1 & 2 & 2 & 3 \\
Argentina & 19 & 13 & 18 & 25 & 25 & 495 & 52 \\
Uruguay & 6 & 7 & 8 & 18 & 29 & 32 & 41 \\
\hline
\end{tabular}

Source: Prepared by the authors using data from INTAL (1997).

TABLE 9

Mercosur: Intrazonal imports of member countries, 1988-1996

(Percentages)

\begin{tabular}{|c|c|c|c|c|c|c|c|c|c|}
\hline Origin & 1988 & 1989 & 1990 & 1991 & 1992 & 1993 & 1994 & 1995 & 1996 \\
\hline Brazil & $\ldots$ & 14 & 9 & 6 & 6 & 2 & 4 & 22 & 25 \\
\hline Argentina & 31 & 24 & 4 & 11 & 18 & 14 & 18 & 23 & 39 \\
\hline Uruguay & $\ldots$ & 71 & 67 & 59 & 60 & 50 & 55 & 41 & 41 \\
\hline Total & $\ldots$ & 100 & 100 & 100 & 100 & 100 & 100 & 100 & 100 \\
\hline
\end{tabular}

Source: Prepared by the authors using data from INTAL (1997).

TABLE 10

Mercosur: Intrazonal footwear exports, 1990 to 1996

\begin{tabular}{|c|c|c|c|c|c|c|c|}
\hline & 1990 & 1991 & 1992 & 1993 & 1994 & 1995 & 1996 \\
\hline \multicolumn{8}{|c|}{ A. Thousands of dollars } \\
\hline Argentina & 5798 & 8959 & 6003 & 13620 & 17484 & 51566 & 37458 \\
\hline Brazil & 9400 & 15816 & 27194 & 44856 & 45665 & 51782 & 66014 \\
\hline Uruguay & 1357 & 3261 & 6580 & 7869 & 8506 & 6670 & 7985 \\
\hline Paraguay & 5 & 372 & 39 & 32 & 81 & 12 & 133 \\
\hline Mercosur & 16560 & 28408 & 39816 & 66377 & 71736 & 110030 & 111590 \\
\hline
\end{tabular}

B. Percentages

\begin{tabular}{lrrrrrr} 
Argentina & 35 & 32 & 15 & 21 & 24 & 34 \\
Brazil & 57 & 56 & 68 & 68 & 64 & 47 \\
Uruguay & 8 & 11 & 17 & 12 & 0 & 0 \\
Paraguay & 0 & 1 & 0 & 12 & 0 & 0 \\
Mercosur & 100 & 100 & 100 & 100 & 100 & 0 \\
\hline
\end{tabular}

Source: Prepared by the authors using data from INTAL (1997). 
TABLE 11

Mercosur: Intrazonal footwear imports, 1990 to 1996

\begin{tabular}{|c|c|c|c|c|c|c|c|}
\hline & 1990 & 1991 & 1992 & 1993 & 1994 & 1995 & 1996 \\
\hline \multicolumn{8}{|c|}{ A. Thousands of dollars } \\
\hline Argentina & 134 & 4857 & 19678 & 18113 & 25570 & 25954 & 45702 \\
\hline Brazil & 1620 & 2019 & 687 & 600 & 3507 & 43689 & 50527 \\
\hline Uruguay & 1975 & 4732 & 7473 & 10540 & 12495 & 10096 & 13141 \\
\hline Paraguay & 436 & 373 & 790 & 3530 & 4777 & 9665 & 7806 \\
\hline Mercosur & 4165 & 11981 & 28628 & 32783 & 46349 & 89404 & 117176 \\
\hline \multicolumn{8}{|c|}{ B. Percentages } \\
\hline Argentina & 3 & 41 & 69 & 55 & 55 & 29 & 39 \\
\hline Brazil & 39 & 17 & 2 & 2 & 8 & 49 & 43 \\
\hline Uruguay & 47 & 39 & 26 & 32 & 27 & 11 & 11 \\
\hline Paraguay & 10 & 3 & 3 & 11 & 10 & 11 & 7 \\
\hline Mercosur & 100 & 100 & 100 & 100 & 100 & 100 & 100 \\
\hline
\end{tabular}

Source: Prepared by the authors using data from INTAL (1997).

TABLE 12

Mercosur: Intrazonal trade balance of the footwear sector, 1990 to 1996

(Thousands of dollars)

\begin{tabular}{|c|c|c|c|c|c|c|c|}
\hline & 1990 & 1991 & 1992 & 1993 & 1994 & 1995 & 1996 \\
\hline Argentina & 5664 & 4102 & -13675 & -4493 & -8086 & 25612 & -8244 \\
\hline Brazil & 7780 & 13797 & 26507 & 44256 & 42158 & 8093 & 15487 \\
\hline Uruguay & -618 & -1471 & -893 & -2671 & -3989 & -3426 & -5156 \\
\hline Paraguay & -431 & -1 & -751 & -3498 & -4696 & -9653 & -7673 \\
\hline
\end{tabular}

Source: Prepared by the authors using data from INTAL (1997).

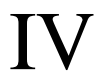

\section{Static and dynamic effects attributable to the zonal integration process}

\section{Analysis of economic effects of a static nature}

Static-type analyses of integration and trade liberalization processes generally seek to ascertain the extent to which these processes reduce the static distortions created by trade protection. From this point of view, trade liberalization and zonal integration are undoubtedly bringing static benefits to the three countries studied. Imports have grown considerably, displacing national production and increasing the variety of products (in terms of both design and quality) available to consumers. Furthermore, in the case of Argentina average import prices have always been lower than the estimated average prices of domestic products, so it might be said that competition from imported products has disciplined domestic prices.

At the same time, the zonal integration and trade liberalization processes would also appear to have generated static benefits on the export side, with the countries of Mercosur increasing their exports of both footwear and leather (an area where Argentina and Uruguay have comparative advantages in static terms). 
Hitherto we have dealt with the static effects of the general trade liberalization process at the extrazonal level (unilateral liberalization) and at the intrazonal level (integration). We should now consider whether or not the zonal integration process in itself has generated benefits of a static nature.

Assuming that the productive resources released by protected activities are spontaneously redeployed in sectors with genuine comparative advantages (generating greater profitability than in the past), Vinerian analyses tend to centre on the behaviour of imports and on the way these displace imports from other origins (trade diversion) or inefficient national production (trade creation). It needs to be asked, then, whether Mercosur has generated trade creation or diversion. ${ }^{6}$ Using extrazonal and intrazonal imports as the basis for analysis, the answers vary depending on the period of analysis chosen.

One option is to compare the situation as it was in any year of the 1990s with what it was before the regional integration process began in January 1991. Since the Mercosur countries imported virtually no footwear in the late 1980s, the answer will obviously be that there has been no trade diversion (imports that never existed cannot have been displaced).

A second option is to follow the sequence of zonal trade liberalization and integration more closely. When this is done the results are very different. The integration process in the footwear sector has had a dynamic that in some respects differs from that of the unilateral trade liberalization process undertaken by the countries of Mercosur. Two major stages can be identified:

i) Between 1991 and 1994 unilateral trade liberalization advanced in the sector while the zonal integration process had serious shortcomings (see section II).

ii) From 1995 onwards zonal integration (tariff preferences) went forward while the unilateral trade liberalization process was partially reversed.

When the situation in 1996-1997 is compared with that in 1992-1994, the Argentine case shows some signs of trade diversion from the rest of the world to Brazil (table 13).

It is found, then, that with a production level that is almost constant between the two averages, Argentine footwear imports from the rest of the world fell by an average of US\$ 24 million, while imports from Brazil

\footnotetext{
${ }^{6}$ Although discussions couched in terms of trade creation and diversion are encountered throughout the specialist literature on the subject, there are very difficult methodological problems involved in arriving at empirical estimates.
}

TABLE 13

Argentina: Imports from Brazil and from the rest of the world (Millions of dollars)

\begin{tabular}{lccc}
\hline & $\begin{array}{c}\text { Annual average } \\
\text { for the period } \\
1992-1994\end{array}$ & $\begin{array}{c}\text { Annual average } \\
\text { for the period } \\
1996-1997\end{array}$ & Difference \\
\hline $\begin{array}{l}\text { Imports } \\
\text { from Brazil }\end{array}$ & 13.0 & 46.0 & +33.0 \\
$\begin{array}{l}\text { Imports } \\
\text { from the rest } \\
\text { of the world }\end{array}$ & 114.1 & 90.0 & -24.1 \\
Local production & 993.3 & 994.5 & +1.2 \\
\hline
\end{tabular}

Source: Prepared by the authors using data from the National Institute of Statistics and Censuses (1997).

increased by US\$ 33 million. ${ }^{7}$ The presumption that trade diversion took place is given credence by the fieldwork done in Brazil, which points to the conclusion that neither the type of footwear exported to Argentina nor the identity of the companies exporting it are the same as are involved in Brazil's exports to the rest of the world.

Something similar may have occurred in Brazil, although to a lesser degree. The change in trade policy that took place in 1995 may have contributed to the transformation in the structure of import origin seen between 1995 and 1997: whereas imports from within Mercosur grew by US\$ 18 million, imports from outside the zone fell by US $\$ 22.5$ million.

In many cases, trade diversion (which always entails a loss of static efficiency) is the result of trading behaviour that reflects the dynamic gains (exploitation of economies of scale, product specialization, dissemination of technological know-how, learning effects, etc.) resulting from the integration process. Unfortunately, as we shall see in the following subsection, these dynamic gains have been relatively modest, so that the trade diversion detected here needs to be evaluated essentially on the basis of its static effects.

Considering the production complex as a whole, the orientation of trade growth in the context of Mercosur seems to have been towards greater product specialization and consolidation of static comparative advantages. In this process, Brazil came to specialize in the more labour-intensive segment (with greater value added) of the production chain (footwear) while

\footnotetext{
${ }^{7}$ Preliminary figures for 1998 show Brazil's share of total Argentine footwear imports continuing to grow (to stand at $45 \%$ ).
} 
Argentina and Uruguay consolidated their position as exporters in the leather segment, where they have natural comparative advantages. ${ }^{8}$

\section{Dynamic effects of the Mercosur integration process}

As was seen in section III, the footwear sector in Mercosur is undergoing a marked transformation. Numerous footwear producers have shut down in Argentina and Uruguay, and to a lesser extent in Brazil, and the surviving firms have adopted a great variety of strategies.

To what extent has zonal integration influenced this transformation process? Fieldwork carried out in Argentina, Brazil and Uruguay shows that, at least in the view of those actually involved, it has had less influence than other factors:

In the case of Argentina, less importance is attributed to zonal integration as a trigger for the changes that have occurred than to the trade liberalization and macroeconomic stabilization processes.

In the case of Brazil, more than a third of the companies interviewed admitted that they had not changed the way they conducted their businesses as a result of Mercosur. The main factors behind the recent performance of the sector, according to them, were the exchange-rate effect and monetary tightening resulting from the Plan Real and the devaluation of the SouthEast Asian currencies, developments that led to a deterioration in the competitive situation both in the local market and in export ones (notably the United States, where there has been a sharp rise in imports of Chinese footwear), and, more recently, the devaluation of the real.

In the case of Uruguay, the general feeling among the employers interviewed was that the current situation in the sector was not the direct result of the integration process, but was rather due to other factors such as the exchange-rate situation (in conjunction with a reduction in export reimbursements), a lack of public-sector incentives and the competition being generated both by imports from South-East Asia and by informal and smuggling activity.

Again, in Uruguay and Argentina zonal integration is seen as an asymmetrical and essentially negative

\footnotetext{
${ }^{8}$ Brazil moved up from third place among countries of origin for Argentine imports to first place. At the same time, exports of Argentine leather to Brazil increased ninefold between 1988-1989 and 1995-1996.
}

process for the sector, with the main gainer being Brazil. Some of the areas where the integration process might have been expected to produce positive dynamic effects are described below.

\section{a) Competitive pressure and industrial conversion in the sector}

The main effect of Mercosur on Argentine and Uruguayan footwear firms has been to increase markedly the competitive pressure exerted by imports from member countries (from Brazil in the case of Argentina, and from Argentina and Brazil in the case of Uruguay).

Of the fifteen firms canvassed in Argentina about the effects of zonal integration, seven spoke of losing local market share to Brazilian producers. In these cases competition had come about both directly and through the displacement of demand towards lower-priced footwear in which Brazil is more competitive. In the Argentine case it might be pointed out that the increased competitive pressure generated by integration has helped stimulate the technological modernization and productivity improvements that have been a feature of the sector there. ${ }^{9}$

However, the response of Argentine companies to the competitive challenge created by imports (from Mercosur and from the rest of the world) was very varied.

In the sports footwear segment, the leading companies sought to maintain their position by obtaining or renewing licences for international brands, introducing state-of-the-art technology and substantial organizational changes and increasing product specialization. Meanwhile, although they continued to be essentially manufacturers, they also adopted the strategy of supplementing their local output with imported products and, to a lesser extent, of disintegrating the production chain by importing shoe parts. ${ }^{10}$ Only in the case of Alpargatas Calzados S.A. was an aggressive export strategy seen. This was pursued largely by obtaining the

\footnotetext{
${ }^{9}$ The effects of the competitive pressure generated by the countries of Mercosur themselves should not be overstated. In the case of Argentina, the high level of penetration by Brazilian products is a relatively recent phenomenon owing to the fact that tariff preferences only began to become significant in 1995-1996 (as extrazonal barriers were raised and intrazonal tariffs came down), so it cannot be considered responsible for sectoral transformations that largely took place before 1995 .

${ }^{10}$ All the business groupings involved with sports footwear production had a negative trade balance.
} 
Nike licence to sell in Brazil and by exploiting the company's own Topper brand in South American markets.

Smaller companies in this segment behaved differently: some of them shut down, others scraped by in limited local markets and the rest were obliged to change their line of business.

Now that prices have stabilized, however, and brands have been strengthened by the use of licensees, the big transnational footwear companies have sought to take back control of their brands in order to supply the market with products imported from their factories in South-East Asia. Thus, the main domestic sports footwear producers have found it increasingly difficult to renew licences, and this is the biggest medium-term threat to domestic production.

In the non-sports footwear segment, the situation of Argentine producers is different. The companies involved are smaller and have found it more difficult to come up with a coherent approach to restructuring. They have tended to concentrate on the domestic market and increase product variety (despite the diseconomies of scale) to capture different market niches. Again, smaller companies have not had the capacity to apply more defensive restructuring strategies, such as using their marketing network to distribute imported footwear or import shoe parts. Medium-sized and larger companies in this segment have made more use of such defensive strategies, and in some cases the importing business has been gaining more and more ground over local manufacturing. By contrast with what has happened in Brazil, Argentine firms have made very little effort to cooperate among themselves, and the agreements that have been arrived at have been short-lived.

A similar situation seems to have arisen in Uruguay, as the strategies the companies interviewed set store by were specialization in producing for niches less exposed to international competition (smart men's shoes or country footwear) and use of their marketing networks to distribute imported products. ${ }^{11}$

In Brazil, on the other hand, zonal integration has not greatly added to the competitive pressure felt by local industry. For a large majority of the companies interviewed, imports from Mercosur that competed with their products accounted for less than $10 \%$ of the local market, and furthermore were stable or declining. None

\footnotetext{
11 In this case, too, the impact that the increased competitive pressure generated by Mercosur may have had should be put in perspective, as imports from the rest of the world are more significant both absolutely and in terms of growth rates.
}

of the firms consulted said they had reduced production because of intrazonal imports.

In conclusion, Mercosur has meant greater competitive pressure for companies in the footwear sector in Argentina (which is increasing as intrazonal tariff barriers come down) and in Uruguay, but the same is not true for companies in Brazil. The effects of this increased competitive pressure on the strategic decisionmaking of Argentine and Uruguayan firms should not be underestimated just because the tendency is a recent one in Argentina and not so marked (as regards extrazonal imports) in Uruguay. In any event, the intrinsic weaknesses of the sector and the absence of a favourable environment have meant that this increased competitive pressure has in the main been responded to defensively, for example by producers gradually turning themselves into importers. In the few cases where a more aggressive restructuring strategy has been seen (for example in the case of Alpargatas Calzados S.A. in Argentina), the outcome of this strategy will be greatly affected by the tendency of big international brands to restrict the licences they grant to local firms as time goes on.

b) Dealing with an expanded zonal market, capitalizing on economies of scale and coverage and learning about exporting

The effects that the expansion of the subregional market is having on Mercosur companies do not seem to be critical. They are most in evidence in Brazil and in a few isolated instances in Argentina and Uruguay.

Clearly, it is Brazilian firms that have taken the greatest advantage of Mercosur to expand their intrazonal exports: $40 \%$ of the firms approached said they had increased output thanks to Mercosur, while a third claimed that they had developed new products tailored to the preferences of consumers in other member countries. Looking to the future, a third of the companies said that in future they would concentrate their greatest selling efforts on the Mercosur countries.

Although intrazonal footwear exports increased substantially in the late 1980s as a share of the total, the proportion of Brazil's sectoral exports and total footwear output that they account for is still very low, at $8 \%$ and $4 \%$ respectively in 1998 . Consequently, the possible impact of these trade flows on production costs in the form of economies of scale should not be overestimated. Nor have substantial changes been seen in business behaviour (such as product specialization with companies in the zone, or mergers and acquisitions). 
It should be emphasized, though, that the export opportunities opened up by Mercosur have enabled Brazilian firms that have traditionally focused on the domestic market (including sports shoe manufacturers) to commence export operations, with the consequent learning effects that may help them to expand their operations outside the zone in future. Again, some companies that have traditionally exported women's footwear have used the Argentine market to break into own-brand exporting.

Argentine footwear firms have not yet succeeded in exploring the large Brazilian market adequately. Only three of the fifteen Argentine firms surveyed said they had penetrated it. One of them (Alpargatas Calzados S.A.) has achieved this essentially because of a temporary licence issued by Nike International to market its brand in Brazil, which casts doubt over the sustainability of the company's activities in the coming years. ${ }^{12}$ The other two firms, which have been exporting mid- and high-range non-sports footwear, have been relatively unsuccessful, either because of poor profitability or because of non-payment problems partly brought about by the import financing restrictions imposed by the Brazilian Government.

Argentine firms have had greater success in the Uruguayan market and, to a lesser extent, the Paraguayan one. However, it is difficult to specify how much influence zonal integration has had on this process, since the same firms that say they export to Uruguay and Paraguay also export to other Latin American countries where they do not enjoy any trade preference. Besides, the Uruguayan and Paraguayan markets are smaller. Thus, for the companies consulted (except for Alpargatas Calzados S.A.), the prospects of achieving greater economies of scale because of zonal integration have been virtually nil. Sluggish exports, combined with loss of local market share and stagnant consumption, have also limited the prospects for profiting from greater product specialization. ${ }^{13}$

Meanwhile, most of the Mercosur companies that have succeeded in exporting footwear within the zone

\footnotetext{
12 The operations of this firm alone would account for almost the entire increase in Argentine footwear exports to the Brazilian market since 1995.

${ }^{13}$ In early 1993, UNIDO (1993) predicted that the Brazilian footwear industry would dominate domestic markets for low-priced footwear
}

already had substantial exporting experience, so it can be said that the impact of subregional integration on learning has not been very significant.

In Uruguay, the subregional integration process has given rise to an increase in the sector's exports to Argentina but not to Brazil. Even so, the bulk of Uruguayan footwear exports still go to markets outside the zone.

The fact that the extrazonal exports of Argentina and Uruguay dropped in absolute terms over the course of the 1990s shows that subregional integration has not served as a launch pad into new markets either.

In conclusion, it can be deduced that Mercosur has generated some dynamic benefits in terms of production scale, economies of coverage and export learning effects, mainly in Brazil. The inability of the Uruguayan footwear industry and the Argentine non-sports footwear segment to penetrate the Brazilian market has limited these benefits for those two countries.

\section{c) New technology, the dissemination of know-how and improved access to raw materials and inputs}

One area in which there do seem to have been some positive dynamic effects is the dissemination of technology and know-how. Five of the fifteen firms interviewed in Argentina had purchased capital goods produced in Brazil. Another three said they had introduced organizational techniques used in Brazilian firms and, more significantly still, two firms declared they had hired Brazilian engineers or overseers to work on their industrial restructuring programmes. Another eight, furthermore, said that zonal integration had improved access to raw materials and inputs.

None of the field studies, however, detected any "deep integration" initiatives, such as cooperation agreements going beyond mere distribution of imported products, complementary production systems or the establishment of factories in other Mercosur countries (although distribution companies have been set up).

while Argentine and Uruguayan producers would do the same in the higher segments. Six years on it could be seen that only the first part of the UNIDO forecast had become reality. 
V

\section{By way of conclusion: inherited advantages and acquired advantages}

The footwear industries of the different Mercosur countries entered the 1990s in very different positions. The Brazilian industry had created and consolidated competitive advantages: its production chain was well structured (there were good suppliers of inputs and parts, companies producing capital goods for the sector and specialist occupational training institutions) and its exports had penetrated the main international markets. This progress was facilitated by a high geographical concentration of production, which made it possible to capture externalities, and by the collective efforts of companies themselves to resolve their competitive problems by setting up industrial associations, training centres and trade organizations. Compared with countries like Italy, however, Brazil does not appear to have made much progress in developing its own designs, a situation that may limit its role in the sector in future; interaction with Argentine companies in this area may help increase Brazilian potential.

The footwear industries of Argentina and Uruguay, on the other hand, entered the 1990s in a totally different position. Firstly, macroeconomic instability and the fitfulness of public- and privatesector export promotion efforts (which peaked in both countries in the mid-1970s) prevented them from consolidating their export position and thus restricted their development to a relatively small and sluggish domestic market. Secondly, the ingredients for systemic competitiveness were not in place as, by contrast with the situation in Brazil, the industries supplying inputs and machinery could not develop properly owing to a lack of joint initiatives by companies. Lastly, institutional mechanisms for supporting technological innovation and occupational training were not strong enough.

In the case of Argentina, this situation in the footwear sector contrasted greatly with that of the leather industry which, after a period of high investment and modernization (in some cases sustained by large public-sector incentives), appeared to be competitive and well equipped for exporting.

The great challenge for the Argentine and Uruguayan footwear industries was to modernize and capitalize on the natural comparative advantages provided by their leather industries to create dynamic advantages in the next links of the production chain (footwear and leather goods). However, unilateral trade liberalization tended to reinforce a form of trading based on natural advantages, which translated into strong growth in leather exports and a marked deterioration in the trade balance of the footwear sector.

The zonal integration process seems in many respects to have worked in the same direction as unilateral trade liberalization. None of the static or dynamic benefits that could be generated by this process -and not by one of unilateral trade liberalization- seem to have had a decisive influence in Argentina or Uruguay (except, so far, growth in Argentine exports of sports footwear to Brazil). Nonetheless, from the way Argentine and Uruguayan exports have behaved it can be seen that Mercosur has ended up becoming the destination for exports which previously went to the rest of the world and which, for a variety of reasons, became less competitive with the products of other supplier nations.

Meanwhile, the large initial differences in maturity and competitiveness that separated the region's industries, combined with major regulatory asymmetries that have not yet been subjected to community discipline, have prevented zonal integration giving rise to a form of industrial specialization that can provide a platform for capturing new markets outside the zone. Thus, there is a tendency towards entrenchment of a kind of sectoral specialization in which Argentina and Uruguay reinforce their role as providers of leather while the market share of Brazilian footwear in the region grows.

In Mercosur, macroeconomic developments, unilateral trade liberalization vis-à-vis the rest of the world and the tendency for apparent consumption levels to stagnate (Argentina) or fall sharply (Brazil) have led to production and employment levels declining and to a relative deterioration in the trade balance of the sector (which is still positive, however, thanks to the solid exporting position that has been maintained by Brazil).

In future, if the aim is for the subregional integration process to be justified by dynamic development of the footwear industry in all member countries, both 
national governments and Mercosur as a whole will have to consider:

i) putting in place the conditions for fair competition within the subregion by harmonizing investment and export incentive policies and phasing out explicit and implicit trade barriers;

ii) developing national policies of a horizontal nature that facilitate the productive and technological restructuring of companies in the sector, ensuring they have access to credit on competitive terms and can introduce new technologies, improving management capabilities and decision-making and promoting the internationalization of business strategies, and

iii) taking action in Mercosur to develop community policies that encourage intra-industry specialization and complementary production systems, and to establish coordinated strategies between companies so that these can compete with extrazonal suppliers both in local markets and in those of the rest of the world.

\section{Bibliography}

CLAVES (1997): Calzado e indumentaria deportiva. Informe sectorial, Buenos Aires, mimeo.

Correa, P. (1999): Impacto setorial dos processos de integração subregional. O caso de calçados, Rio de Janeiro, Centre for Foreign Trade Studies Foundation, mimeo.

Da Costa, A.B. (1993): Competitividade da indústria de calçados. Estudo da competitividade da indústria brasileira, Campinas, Brazil, State University at Campinas/Centre for Foreign Trade Studies Foundation.

Humphrey J. and Schmitz H. (1996): The triple C approach to local industrial policy, World Development, vol. 24, No. 12, Oxford, U.K., Pergamon Press.

INTAL (Institute for the Integration of Latin America and the Caribbean) (1997): Sistema de estadísticas de comercio de América, Buenos Aires.

Laens, S., R. Osimani and A. Failde (1999): Sector calzado. El caso de Uruguay, Montevideo, Economic Research Centre (CINVE), mimeo.

Ministry of Industry and Foreign Trade (1997): Sector calzados. Comercio exterior y medidas arancelarias, Buenos Aires, mimeo.
National Institute of Statistics and Censuses (1994): Censo nacional económico, Buenos Aires.

(1997): Anuario estadístico, Buenos Aires.

Schmitz, H. (1997): Collective Efficiency and Increasing Returns, IDS Working Paper, No. 50, Brighton, U.K., University of Sussex, Institute of Development Studies (IDS).

Schmitz, H., and P. Knorringa (1999): Learning from Global Buyers, IDS working paper, No. 100, Brighton, U.K., University of Sussex, IDS.

UNIDO (United Nations Industrial Development Organization) (1993): Medium-term scenarios for industrial restructuring: the leather and footwear subsector, Vienna, mimeo.

(1995): International Yearbook of Industrial Statistics 1995, Vienna.

(1996): International Yearbook of Industrial Statistics 1996, Vienna. 